\title{
Article \\ Time, Space and Agency in the Finnish Cultural Sector at the Time of COVID-19
}

\author{
Arja Haapakorpi ${ }^{1}\left(\mathbb{D}\right.$, Minna Leinonen ${ }^{1, *} \mathbb{(}$ and Katri Otonkorpi-Lehtoranta ${ }^{2}$ \\ 1 Work Research Centre, Tampere University, 33014 Tampere, Finland; arja.haapakorpi@tuni.fi \\ 2 Work Community Development-Study Program, Humak University of Applied Sciences, 00400 Helsinki, \\ Finland; katri.otonkorpi-lehtoranta@humak.fi \\ * Correspondence: minna.leinonen@tuni.fi
}

Citation: Haapakorpi, A.; Leinonen, M.; Otonkorpi-Lehtoranta, K. Time, Space and Agency in the Finnish Cultural Sector at the Time of COVID-19. Challenges 2022, 13, 4 . https://doi.org/10.3390/ challe13010004

Academic Editors:

Palmiro Poltronieri and Susan

L. Prescott

Received: 17 December 2021

Accepted: 18 January 2022

Published: 31 January 2022

Publisher's Note: MDPI stays neutral with regard to jurisdictional claims in published maps and institutional affiliations.

Copyright: (c) 2022 by the authors. Licensee MDPI, Basel, Switzerland. This article is an open access article distributed under the terms and conditions of the Creative Commons Attribution (CC BY) license (https:// creativecommons.org/licenses/by/ $4.0 /)$.

\begin{abstract}
The organization of working times and workplaces has typically been diverse and hybrid for people working in culture. Work is characterized by precarious conditions such as short-term contracts and seasonal employment. The impact of COVID-19 has shown the vulnerability and uniqueness of the employment conditions in this sector. We collected personal written texts from people working in the cultural sector in spring 2020, when in Finland the first wave of COVID-19 was subsiding and nobody knew when the next wave would come. We analyzed the ways cultural workers constructed agency on temporal and relational dimensions as regards work and non-work. The content analytic approach highlighted two main types of situational agencies, the normative employment agency and the precarious work agency, both of which were shaped by the uncertain conditions of the cultural sector. Due to the differing employment conditions, both intensification of work and small agency were present in work of the cultural sector and posed challenges to the management of time and the future. However, the terms and conditions for agency construction varied, even under similar circumstances.
\end{abstract}

Keywords: agency; COVID-19; cultural sector; precarious employment; small agency

\section{Introduction}

The world-wide emergency due to the COVID-19 virus has resulted in a variety of social, economic and cultural restrictions and regulations in addition to the direct impact on health (e.g., [1,2]). However, the consequences have been in many ways uneven as regards employment and work, such as the personnel in health services being exposed to the virus and the employees in market-based services losing their jobs because of the strict regulations. (e.g., [3,4]) The government of Finland set regulations related to the COVID-19 pandemic in March 2020. The social distancing limitations caused the closing of public interiors and public meetings were restricted to 10 persons, which was later relaxed to some extent, which forced the cultural sector to halt their activities or transfer them to the future [5,6]. In many sectors, such as tourism [7,8] and the cultural sector [6,9] in which work and income are based on communication with the audience, but with no status of obligatory service provision like health services, the impacts of the COVID-19 pandemic have been dramatic. In this article we focus on the cultural sector in Finland. The COVID-19 pandemic has closed down activities in the cultural sector to a large extent and particularly those in the performing arts. Unemployment and shortage of assignments for the selfemployed have been the consequence in the industry. The impact on employment has been particularly negative in the cultural sector, as during the first wave of the pandemic, the growth in unemployment was 57\% (v). The consequences of COVID-19 for cultural sector employment and activities varied. The municipalities and NGOs reported less serious impacts on their activities, for the proportion of those with serious impacts was $22-27 \%$ compared to the private sector and individual professionals with their $74-76 \%$ proportion. Individual professionals evaluated the lost or cancelled assignments and employment 
opportunities to be $93 \%$, but $44 \%$ of them reported new job opportunities [10]. However, employment in the cultural sector is often underestimated in official statistics for many reasons, but in particular the structures of employment (OECD 2020), which also applies the era of the pandemic [11].

High technological infrastructure and the related qualifications of the workforce are described to be typical for Finland [12]. During the pandemic, distance work with virtual connections was used by those for whom it was feasible, about half of the workforce [13]. The proportion is high and also includes employment opportunities provided by technology for the workforce in the cultural sector. However, replacing social events with virtually mediated services is limited for many reasons, such as high expenses and limited demand due to the lack of social contact [14]. Although culture is valued during hard times [15,16], people are not ready to pay high fees for cultural services [17], and, for example, in social media, culture services are available free of charge.

In European countries, economic support has been allocated to the cultural sector [6]. However, the support has been directed to established culture institutions to guarantee their continuity and a promise for future activities, but the artists and professionals in the industry with their atypical employment pattern have been dismissed to a large extent [14]. The reason is embedded in their position outside the labor market institutions and the permanent channels of welfare systems, such as unemployment benefits as the funding has carried out through institutionalized channels [14]. Multiple job holding, a mixture of different patterns of sourcing income is not recognized in welfare systems, which are based either on the employee position or entrepreneurship. During the pandemic, the marginal position of cultural sector workers was revealed, although it has been commonplace for a long time. The economic support has been addressed to the cultural sector via the Ministry of Education and Culture, the Ministry of Economic Affairs and Employment, municipalities, and NGO's [18]. Despite the variety of sources, numerous artists and professionals in the cultural field, mostly multiple job holders, were not entitled to support in Finland.

Our contribution to the studies on the emergency focuses on the artists and professionals in the cultural sector, for we assume that the essential consequences will manifest in the living spheres of this group. We imply not only the ongoing emergency but the possibility of similar phenomena in the future of the globalized world.

Finland as a case study represents a particular country with respect to introducing new technologies, which also applies to the cultural sector. However, the workforce in the sector shares terms and conditions with other Western countries in respect to employment before and during the pandemic. Thus, we assume similarities regarding the work with other Western countries in Europe, but also specific reshaping of work through technology. As the pandemic may raise the significance of virtual technology at work also in the cultural sector, we ask, if it is related to agency.

We begin the article with a presentation of the employment position and work profile of artists and professionals in the cultural sector in Western countries and particularly in Finland to frame the subject of the study. After that, we outline our theoretical approach on the basis of the literature on agency in the context of precarious work. Presentation of the data and methodology follows. The analysis, interpretations, conclusions, and discussions are the core of our contribution.

\subsection{Between Employment and Calling}

In 2018, the proportion of the labor force in the creative sector was $3.8 \%$ of the total labor force in Europe, while in Finland, the proportion was somewhat higher, 5\% of the total labor force. These are well-qualified individuals, for higher education is fairly commonplace for professionals in the cultural sector, with $59 \%$ holding a tertiary-level qualification and in Finland with $60 \%$ holding a higher education degree [19]. Artists and professionals in the cultural sector more often make their living as self-employed persons $(33 \%)$ than is the case in other industries (14\%); in Finland, the corresponding proportions 
are $28 \%$ and $12 \%$, respectively [19]. Earning income from many sources is common; $11 \%$ of these people are multiple job holders, the comparable figure for the average for the labor force in Finland being 6\% [20]. However, the statistical methods for collecting and analyzing data may underestimate the actual proportion as multiple job holding is rarely a permanent employment arrangement and more like a flexible way of organizing one's current projects and income [14].

The cultural sector is heterogenous as it includes a variety of artists and professionals, tasks, positions, and employment patterns.

The parallel patterns of non-paid, calling-based and paid work in the cultural sector have shaped the positions of the professionals and artists, ranging from the market-based and commercial cultural industry to individual work with a risk for precarious employment. [21]. As the commercial and market-based industry is typical for the US, according to Ross [21], the European cultural sector is framed with policy and public sector funding, which does not guarantee more security in employment [22]. The ambiguity in employment shapes the work in the cultural sector and working free of charge sometimes leads to self-exploitation and extreme flexibility [21,23], which is claimed to concern women more [24]. However, with the variety in the sector, people may also adopt a pattern more typical for wage-earners, which is based on negotiations and control over their work and terms of employment [25]. The trend is called "the industrialization of Bohemia" [26].

Due to the hard competition for funding and underemployment in the cultural sector, multiple job holding is a typical employment pattern. Extra sources of income are often necessary in order to ensure sufficient income [27]. The profile of tasks is gendered to some extent, for men tend to have prestigious creative tasks more often than women and women tend to more often take on tasks external to the creative work [28].

The hybridization of income sources and work has been recognized in many studies $[23,27,29]$.

In Australia, half of the working hours are spent on creative work, a quarter on tasks related to arts and culture and the rest are external to artistic work [30]. In Finland, the corresponding proportions are 39\%, 44\%, and 17\% [27]. However, the definition and categorization of artistic or professional tasks is not always clear and the division into artistic work and non-artistic work may depend on the contexts. For example, the same task may be regarded as creative work or external work, depending on the purpose of the task and its relation to other tasks [27].

With the lock-down, a significant number of the performing artists and professionals in the cultural field have lost their employment, assignments, and income. They are marginalized in a special way, for the authorities and institutional agents in the cultural sector express lack of knowledge of their current economic, social, and employment situation [16]. However, people with problems in their living spheres, excluding extremely violent environments, are not passive victims but active individuals with their resources striving to solve their problems. In addition, assumed or imagined futures may reinforce agency with new, hopeful goals. Imagined future creates a mindset based on meaningful trajectories for agency. However, severe circumstances may diminish agency into plain survival and narrow future prospects. Precarious terms of employment may decrease latitude in social, cultural, and individual life, in addition to financial situations.

Our conception of the situation of the artists and professionals in the pandemic era is based on the exceptional lock-down in the cultural sector with hard economic and employment-related problems, but also human agents with their individual, social, cultural, and action capacity. We ask how agency is enacted in time and temporally evolving relational contexts in the written texts of cultural workers and how the financial situation and employment arrangements define possibilities for agency. Our aim is to study artists and professionals in the cultural sector by applying the approach of agency theory engaged with the perspective of small agency, but also to analyze agency through the lenses of precarious employment. The main focus is on work agency and how it is or is not realized. In so doing, this article contributes to the theoretical debates on temporally constructed 
agency by demonstrating the different ways in which the dimensions of agency take in the temporal and relational perspective of actions. As cultural workers responded to the rapidly changing situation caused by the outbreak of the COVID-19 pandemic, they had to reconstruct their views of the past in order to understand the emergent present and to control and shape their responses in the arising future [31]. Thus, our aim is to make the different temporal dimensions of agency visible, in particular in relation to the future. Our analysis begins with the changes in agency caused by the pandemic in relation to precarious employment agency and continues to the perspective of the emerging future and hope.

\subsection{Agency as the Core of the Theoretical Approach}

The concept of agency has long and multi-branched roots that have usually been traced to the Enlightenment debate on the nature of human freedom. In sociological discussions developing primarily out of Enlightenment thought, agency is conceptualized as the relationship between an individual's actions and the surrounding structures that restrict an individual's freedom externally. Since the establishment of sociology, different approaches to agency have placed different emphases on rational choice and individuality in relation to social and cultural structures [32]. However, it seems that all conceptualizations of agency are engaged in the premise that agency always presupposes the existence of both power and freedom.

Our orientation to agency is temporal-relational. We share Emirbayer and Mische's idea that "all forms of agency are temporally embedded in the flow of time" [31]. In our study this means that the ways in which cultural workers understand their own relationship to the past, present, and future make a difference to their agency, agentic possibility and actions. Cultural workers see their world through an agentic possibility that is in relation to the structural, relational, and situated context of the pandemic. The construction of temporal perspectives is an intersubjective process informed by an individual's own reflection, but also influenced by others' viewpoints [31].

In this article, we analyze temporal-relational agency in a framework that utilizes the theorizations of precarious work and focuses on the subjective dimension of precarization [33-37]. It has been claimed that precarious work has made the availability, the permanence, and the quality of jobs more uncertain with consequences not restricted to work but also affecting many non-work domains. Thus, precarious work has an overall impact on an individual's everyday life. We approach precarious work as the nature of labor market working conditions that holistically affect an individual's living conditions.

In addition to precarious work, we complement our perspective of temporal-relational agency with theorizations of agency highlighted in feminist research [38,39]. Honkasalo [38] has used the concept of small agency to draw attention to small-scale ways of acting and knowing, including modes of action that do not aim at change, but at preserving the status quo. This affords an opportunity to extend the view beyond rational action and also takes into account, in addition to activity, passivity and hope, which can mean waiting and enduring. The concept of small agency is especially useful in the context of situations in which forms of agency and agentic possibilities rapidly change and become restricted. In such historical situations, such as COVID-19, the structural context demands actors to reconstruct their view of the emergent present in order to respond to the rising emerging future. Utilizing the concept of small agency is particularly fruitful in our case, since small agency allows addressing simultaneously both dimensions of agency: it can be passive and active at the same time. The concept of small agency offers a useful basis for examining restricted life conditions as experienced by cultural workers when the COVID-19 pandemic to a large extent closed activities in the cultural sector.

\subsection{Precarization as a Mode of Working in the Cultural Sector}

Our perspective on precarization is an individual-centered study of the nature of precarious working conditions and its consequences for an individual worker in the cultural 
sector. We approach cultural work as a precarious mode of working for three reasons. Firstly, cultural work can be examined in the context of job insecurity. We understand job insecurity here as working conditions in which short-term and multiple job holding are a typical employment pattern, periods of employment and unemployment vary and overlap, and incomes remain low. Cultural work is often in short supply, project based, and allocated by informal networks. Insecurity occurs as a fear of loss of employment, in other words, job insecurity can be described as a threat to the continuity and stability of employment.

Secondly, cultural work is an example of flexible work, in which workers typically experience periods of intense work followed by slow periods or even unemployment. However, flexibility does not refer only to the quantitative variability of work. Flexibility extends to a certain mindset that occurs in a readiness to react and adapt to rapidly changing and appearing work opportunities. George Morgan and Pariece Nelligan have termed such flexible workers as labile labor that is "mobile, spontaneous, malleable, and capable of being aroused by new vocational possibilities" [40].

Thirdly, and closely related to the previous characteristic, cultural work is highly individualized. This means that the work becomes more and more attached to the person. It requires an even deeper and more personal and passionate contribution as individuals actively pursue their work careers. Constructing an individual's own biographies has become a duty that requires individuals not only to act, but also to take responsibility for those actions and their productivity. Therefore, responsibilities become individualized.

\subsection{Small Agency in Cultural Work}

Honkasalo [38] has described small agency as 'minimal agency', which refers to acting that can manifest itself as being, waiting, passive reception, and enduring. These modest modes of acting and knowing may suggest that nothing inevitably happens in it, nothing changes, but it is still a significant and functional thing for an individual herself. In the context of cultural work Åkerblad [37] has pointed out that the idea of small agency fits well in the analysis of career breaks or situations, in which working conditions are unsatisfying, for example, due to chained employment relationships. In these situations, space for acting shrinks as options dwindle. Åkerblad has called these situations career hubs. Career hubs are moments with a demand for constructing a new way to act. Choosing a way to act may appear to be almost impossible and the agentic possibilities very restricted. Agency is characterized by a lack of alternatives, as the ways of operating that seem possible are shrinking. The concept of small agency enables us to analyze both the "active" activity needed to cope with the situation and the "small" activity, such as tolerance or endurance. This is relevant for understanding how continuity, which also provides opportunities for the new, is produced.

\section{Data and Methods}

The data were a collection of written texts by artists and professionals in the cultural sector. Data collection took place in spring and summer 2020, in the aftermath of the first wave of the COVID-19 pandemic. The COVID-19 pandemic spread to Finland in late February 2020. The main strategies that the Finnish government adopted were lockdown and physical distancing. The premises of schools and other educational institutions were closed, and contact teaching was suspended and replaced by remote teaching. The government recommended that, whenever possible, children should be cared for at home. However, daycare centers remained open, as well as contact teaching in grades 1-3 for the children of parents working in sectors critical to the functioning of society. The premises of all cultural institutions, such as state and municipal museums, theaters, the National Opera, cultural premises, libraries, and mobile libraries, were closed. The same went for hobby facilities and venues, swimming pools and other sports and youth facilities, organization meeting facilities, day care activities for the elderly and rehabilitative work. These arrangements were in effect for approximately two months, between 18 March and 14 May 2020. The gov- 
ernment restricted public gatherings to ten people and recommended avoiding unnecessary presence in public places. In addition, the government recommended that remote work be preferred whenever and wherever feasible. Some restrictions and recommendations remained in place to some extent throughout 2020.

The data were gathered with a virtual data collection tool Penna of Finnish Social Science Data Archive, Tampere University, which follows the necessary security and confidentiality guidelines. We launched the call and spread it via social media and through e-mails to individuals, agencies, NGOs, public sector institutions, and other relevant actors. We also launched advertising about the call through a radio station. Texts received totaled 34 , and for this research, 29 of the texts were analyzed. The five texts excluded were too short, or they were from the sectors of youth and sports services and did not meet the criteria of cultural work.

The introduction and the themes and questions of the call were as follows:

We are collecting texts on experiences and changes in work dealing with the pandemic COVID19 and hope for a multiplicity of answers to our call. We provide the following themes, but the choice is yours.

Questions and themes:

- How has the emergency shaped the planning of work, the tasks, time resources for work and the pace and schedules?

- If you have lost your job or assignments, do you get unemployment benefit, have you applied for the financial support provided by the authorities or do you have other sources of income?

- Have you found new working methods or patterns (for example virtual channels)? Has the lock-down shaped the content of your work? Are there new dimensions in your work, which seem to be established?

- What decisions have you been forced to make? What about the decisions having an impact on other people (work-related health and safety, income, survival of the work organization, future)?

- Have you been supported by other people, such as your work-site and colleagues? How have the government and society supported you in these hard times?

- Do you have experiences of being treated unequally or being marginalized?

- How do you cope with the lock-down?

- How do you see the future? What kinds of expectations and assumptions do you have?

The description of the data covers information on gender, age (Table 1.), and profession and employment pattern (Table 2). There were 17 women among the respondents and 11 men. Two classified themselves as "other gender".

Table 1. The data categorized by age. Information on age is lacking from one text.

\begin{tabular}{lc}
\hline Age Group & Number \\
\hline 20-30 years & 2 \\
31-40 years & 9 \\
41-50 years & 8 \\
$51-60$ years & 7 \\
$61-74$ years & 3 \\
\hline
\end{tabular}

The employment pattern refers to the era before the lock-down. Those with employment contracts were entitled to unemployment benefit, but the self-employed (entrepreneurs and freelancers) and those with a grant-based income were not entitled such assistance. Most of them had applied for a special, lock-down related grant from the Ministry of Education and Culture, and many of them had received it.

The analysis was carried out using content analysis [41]. First, the data were read through. The coding was based mostly on the themes emerging from the answers to the questions. Although there were similarities in the texts based on the guidelines given to the writers, the texts varied in respect to length and content. The writers focused on the themes 
which were meaningful for them, for example family life and negative impacts on the workplace. In addition, financial situation, changes in work opportunities, powerlessness but also hope emerged from the data. Experiences relating to time and temporal changes were recurrent in the data, likewise the possibilities to act. For a more precise coding, reading focused on descriptions of the changeability of agency in time (the past, present, and future at the time of writing). The possibilities for agency were tied to the economic and employment situations of the writers thus offering an important avenue for further analysis.

Table 2. The data categorized by profession/artistic discipline and employment pattern.

\begin{tabular}{ccc}
\hline $\begin{array}{c}\text { Profession/Artistic } \\
\text { Discipline }\end{array}$ & Performing Arts (13) & Visual Arts (9) \\
\hline Self-employment & 6 & 2 \\
Wage-earner & 6 & 2 \\
Multiple income source & 1 & 2 \\
Grant-based income & & 3 \\
Profession/Artistic & Officials (Library and & Audiovisual Arts and \\
Discipline & Cultural Services) (5) & Multiple Tasks in Perform \\
Self-employment & & 1 \\
Wage-earner & 5 & 2 \\
Multiple income source & & Arts \\
\hline
\end{tabular}

\section{Results}

In the following, the findings are organized into two main sections: changes in agency from past to present and agency in perspectives on the future. In both sections the temporal perspective is defined by the present of the data in the written texts, the first wave of COVID-19 in Finland and its immediate aftermath in spring and summer 2020.

\subsection{Loss and Intensification of Work Agency}

Agency exists and is enacted in a temporal continuum. Agency is also affected by several spatial arrangements. In relation to work agency and the boundaries between work and non-work the analysis brings forth financial conditions that shape agency. Among the cultural workers this could be observed in two distinctive categories: normative employment agency and precarious work agency. Both were based on the understanding that livelihood in the cultural sector was often uncertain even without the pandemic, and people constructed their agency in relation to this understanding. To be clear, these categories were situational and changeable and attached to that particular time and circumstances.

Normative employment agency consisted of the experiences of such writers who had an employment contract, mostly in municipal libraries and in the production of cultural events, but also of such cultural workers who at the time of the first wave of the pandemic had other types of financial support such as unemployment benefit. This type of agency was also limited in the sense that it challenged the boundaries of art as work and non-work and, on the other hand, the boundaries between art and non-art.

When agency is outlined by a normative employment relationship, however briefly, this could mean that one's situation did not match the publicly shared understanding of being a starving artist worthy of Corona-related financial support.

Suddenly it is a blessing to be on unemployment daily allowance... On the other hand, it feels like that I can't apply for grants as I've had no gigs to lose. Quarantine makes my life continue as I did before Corona, home alone. 
The writer had experienced longstanding stress and feelings of exclusion that carried over to the time of lockdown. In the data extract, the woman working in the performing arts expresses that her situation is financially more sound than among others in cultural work, even though it can be expected to be tight anyway. In terms of space, lockdown also does not change her situation of social exclusion. Thirdly, the extract reveals the self-limitation of agency: who is entitled to grants in a situation where extra grants are awarded in order to compensate for artists' loss of income. As always, grants were awarded based on the merits of the application and could, theoretically, lead to the writer taking somebody else's place, somebody who was more needy than her and worthy of the grant.

This type of survivor's guilt functioned as an inducement to the intensification of work for those whose work situation was only slightly affected by the first wave of the pandemic. For those with the opportunity to do remote work this could mean an increase in meetings and contacts with partners and clients with few opportunities for breaks and being laden with the burden of staying in a constant state of preparedness.

I believe that a large part of us working in the arts and cultural administration is driven to overt diligence and over-achievement because of our awareness of how lucky we are to be in this situation. Our work continues at the same time as so many colleagues and wonderful artists have ended up in a really difficult situation. We try to do our part so that at the same time we would prepare as good an opportunity for them to return to work as possible when the corona situation has passed.

(woman, cultural administration)

The people with permanent incomes were grateful to their employers for not being laid off. However, they had to work in alternative, non-professional tasks, as the libraries and other culture institutions were closed. They practiced flexible agency in negotiating with the employer and accepting the alternative tasks.

The ties of normative employment agency to the boundaries of art and non-art were apparent in comparisons between people working in the cultural sector and how art should or was expected to be a part of their work. When faced with difficult circumstances, comparison was also a way to cope in reduced circumstances and with heightened demands on one's time and effort:

Now that I'm approaching retirement age, I realize what a gift I've given myself by staying in a permanent job, even though it's often caused a huge conflict in relation to my artistic work and my well-being. [ ... ] Workload was increased, my part-time teaching hours weren't at all sufficient. On the other hand, I didn't get a pay rise. So, I had to think like this: "I have to be grateful that I didn't lose my job so I'll do even these extra work hours for free and without complaint." I don't know if this kind of gratitude thinking should exist in working life at all. But watching the posts of distressed colleagues on Facebook or pictures of exhausted Spanish nurses online, my own extra work seemed so little that I didn't have the nerve to mention the whole thing.

(woman, visual arts)

Tensions between different types of work and methods of earning one's living were apparent in the data. When resources are scarce, gate-keeping practices become relevant in determining opportunities for agency as in whether one is artist enough to apply for an arts grant. if, for example, one works in entertainment as well. Thus, boundaries between art and non-art were also shaped by the ways of financing one's living.

Precarious work agency was prevalent among those professionals and artists with a portfolio career, in other words, combining entrepreneurship, employment contracts, and grants. Precarious work agency drew its power from the skills of managing uncertainty and managing with low resources. Therefore, the sudden changes in society and in the employment circumstances of the sector were not as shocking as in sectors with more steady employment arrangements. 
[After the year's end] no work presented itself and that has been a regrettably common situation for me at the turns of years. [ . . . I was already in a situation resembling the Corona crisis when it began, and it didn't have a great effect on my life.

(man, performing arts)

Small life strategies included saving from a small income which was a popular way to prepare for the insecure future. Many of the cultural workers were not entitled to unemployment benefits and among them were also artists with an international portfolio career, which had caused them to drop out of the national support systems.

I am not entitled to unemployment benefits and other economic support, [although I have paid my share of the taxes and other institutional fees] because of my international career. I think that is not fair. However, I cannot complain, for I cope in this situation with the savings from the rewards sourced from the events.

(man, performing arts)

Still, when there were expectations of getting into the process of work, many work plans were severely disrupted. Even though work was not necessarily totally impossible, there was a clear inability to enact one's work fully or sometimes even partially and reach set objectives:

I'm in a situation in which I cannot meet my co-workers or go to my research locations where I was supposed to do my work. My work also entails writing, reading, and planning and I've moved on to those activities. But solely by those methods I cannot realize my work the way I had planned. [ ... ] Getting in touch with real life and with my topic concretely would be essential to achieve a good outcome.

(woman, visual arts)

In this data extract, the uncertainty touched more upon the content of the artistic work than financial survival. When in some stories the change in agency meant recovery from the shock in the work situation, others struggled with the sense of time and effort lost.

The Corona pandemic changed this summer completely for me. Although the planning work (mostly getting acquainted with the text, preliminary meetings etc.) had already started. The situation was expected to clear up but it didn't and the whole production was cancelled for the summer. All the work and energy put into it, preliminary planning, ideas and preparations were wasted.

(man, performing arts)

After the COVID-19 shock, an opportunity to withdraw and recuperate was also a privilege. This type of small agency was present in stories, where abilities to act were severely restricted but the scope and level of agency could be altered, often led by a change in the focus of one's activities.

As regards creativity, agency could be both sustained and limited. For some, creative work was something they engaged in to survive the restricted circumstances, but for others it proved to be more difficult to carry on:

I noticed my creativity was paralyzed in front of fear. The sharpness of thought has blunted [...] It is difficult to fulfill the criteria for a grant and come up with new productions all the time.

(woman, visual arts)

Changes in the spatial and temporal arrangements of work and indeed other aspects of people's lives could also provide relief for those whose workload had been heavy before the pandemic, and even more so if they had family responsibilities:

Permanent actors in theaters today work like crazy, two times a day, six days a week. Summer months are spent in mental and physical recuperation. [ ... ] I was astounded for a while [when the children stayed home because of lockdown], but the new everyday 
life felt like a relief compared to our normal everyday life. Suddenly nobody was running to get to rehearsals, competitions, gigs, bars or anything. Or course I was temporarily laid off but as a salaried person the union gives back.

(woman, performing arts)

Gaining space and time meant the opportunity to lighten the future workload by getting back to work tasks that were left hanging because of the otherwise busy schedules, to consume overtime hours, to distance oneself from intense working thus also providing space for thinking and creativity. For example, an artist mused that the "empty phase" she was in was a kind of a precursor for artistic activity. For her, there was a work process one can rely on that will carry one from small agency to the next stage.

\subsection{Resources for Work Agency and Changed Methods of Work}

To gain and sustain agency needs resources. When burdened with financial concerns and limitations on work agency, cultural workers created structures for their daily lives and tried to find different ways to cope. To work in uncertain circumstances was a skill acquired already before the pandemic and for some this meant an elevated state of agency, where the ability to manage one's time and space were key. Those practicing normative employment agency could find new ways to organize their work. For example, in remote work there could be more autonomy regarding scheduling one's work.

For those practicing precarious work agency, the positive approach was emphasizing the freedom to concentrate on meaningful and significant artistic work or on the development of artistic skills despite the worsening economic situation. The negative approach was related to insecurity about doing unpaid work, particularly if the "calling-based" work required expensive infrastructure. Thus, in a way their activity and passivity were conflicting between the tension of calling and paid work.

I could develop my activities and services in my studio [working on audiovisual services], which implies updating my instruments and equipment and competence and building new customer relations. However, it is slow, based on competition and, again, outside any economic support.

(man, musician and professional in audiovisual technologies)

The opportunity to modify one's work or try out new methods was dependent on both the work processes and the type of agency.

However, limiting the state of emergency was for people working in the cultural sector, arrangements that safeguarded their health were also appreciated. From that perspective, new forms of work such as remote work and virtual, digital methods were appreciated.

New methods of working provided a wider scope for agency and could be resources in themselves, when one had wide control over the work processes one was engaged in. Indeed, such issues as virtual performances and galleries were mentioned in the data. These all can be seen as new methods of work in the cultural sector, at least, because the writers mentioned that they had not worked with them before or now commented on their usability in their written texts. The embodied nature of work cast a shadow over the opportunities to realize work agency virtually, as highlighted by this musician who also worked as a teacher:

The opportunities for remote teaching with my instrument seem really difficult at first glance, considering that the age range and level of skill vary greatly among the pupils and, with most of, teaching happens almost hand in hand.

(man, performing arts)

The opportunity to control one's work processes and use time as a resource was also affected by one's family situation. Artists and professionals in the cultural sector are usually presented as individuals with their calling and subjective state of mind and living spheres. However, the relation of paid work/non-paid work and family life came out as a significant frame for the economic situation and working patterns. Boundaries of work and non-work 
were crossed when work and family were confined to the same space: schoolchildren were home during the hardest part of the lockdown and smaller children stayed at home during the days instead of going to kindergarten. With the conflicting duties of care and paid/ unpaid work, time and space management was a challenge. These conflicting demands on one's time could lead to evaluating one's work agency as inadequate:

Being with a small child and running the everyday life, for example preparing the meals for the day, take quite a big portion of the day, and I don't want to burn out. I try to make peace with the fact that I can work only a certain amount in a day but at the same time I continuously wonder whether I am doing enough or get enough done, am I worth the grant [I've received].

(woman, visual arts)

When applicable, two-parent income balanced the vulnerable economic situation of the artists and professionals in the culture field as their spouses had an employment contract and related income. For one single parent, the situation was different, for she takes every job available, regardless of the quality of work. The family-work relationship was harder for a single parent, for it set a tight frame for her activities and removed the opportunity to exercise preferences.

\subsection{Imagining the Future: Holding On or Letting Go of Small Agency}

The agency of the artists and other cultural workers was heavily reliant on the possible futures their perspective was attached to. Flexibility was a way to ensure one's future. The written texts displayed both trust in the future and dread of the realization of the worst-case scenario. The uncertainty of the future made the normative work agency more attractive, and a flexible agent was prepared to put current artistic work on hold get employment in another line of work. The disruption of temporal perspectives, due to the first wave of the COVID-19 virus (cancelled gigs, postponed performances) could emphasize small agency but also means by which cultural workers could stretch the limits of agency.

The pandemic contributed to experiences of exclusion or even of being ostracized in ways that made it impossible to plan for the future. When there was little chance of affecting one's immediate situation, a sense of stagnation marked the attempts to act.

Taking the future as a starting point made agency possible for some. It relieved tension from the necessity to act right now or made it possible to let go of the original plan that was based on cultural events being realized at a certain time. This sense of stagnation could at best be overcome by shifting the focus to the future.

Whether it was a more normative type of work agency or precarious, agency was realized as creating structures for the future. It was about coordinated, determined activities that ensure continuation-even when financial compensation was uncertain:

I've started two new projects. The first one's drama in a way. The other's strictly writing.

I don't know how not to work. It's unlikely I'll get financial compensation for my work.

(woman, performing arts)

The extract highlights action as a necessity, cultural work as a way of life and work in itself as a means to survive. Other ways of creating structures for the future were applying for funding (grants), making and rearranging plans for the autumn, and engaging in sustainable activities that had low demands on resources:

At times I fear that the Corona crisis will be followed by a severe economic depression. However, I invested in equipment before the Corona crisis so a new project awaits and I can realize it on a very low budget. I have faith that this crisis, too, will be overcome.

(woman, visual arts)

Learning and training skills that support employability were another feature in creating structures for future. Also, restrictions on traditional modes of action made it necessary to find new ways of making art and culture available in concrete and virtual spaces. In all, 
creating structures for the future was based on making use of various resources at hand. Also, the disruption of temporal perspectives due to the first wave of the COVID-19 virus (cancelled gigs, postponed performances) meant opening up new possibilities for some of those enacting precarious work agency. When the status quo was shaken, all bets were off and lost chances could also turn into new ones.

The uncertainty of the future made the normative work agency more attractive, and a flexible agent was prepared to put current artistic work on hold get employment in another line of work.

Living the first wave of the COVID-19 pandemic meant inhabiting a liminal space that subverts agency. From the perspective of precarious work agency, the future was open for both negative and positive effects.

A 54-year-old freelancer like myself certainly isn't wanted on the job market. Keeping this in mind, my future in working life is extremely difficult. It has started to look as if there are hardly any job offers and in recruitment situations I'm not chosen. Schedule changes caused by Corona may generate work opportunities for me. Time will tell and there's still hope.

(man, performing arts)

Indeed, the disruption of the normal flow and organization of life could also lead to envisioning alternative futures in a positive sense. There were expectations for a boom of cultural events and for participation in these. Although cultural workers could be forced to find new ways of acting, such new ways could become sustainable when they contributed to artistic agency and work processes. Agency is anchored in the possibility of changing the way of life and in the insight the state of emergency in the society has provided.

I see the future of my work as bright in the sense that I believe this crisis will urge us to consider our most basic values again and I hope that our attention is focused on relevant issues. I hope for the slowing down of consumer culture, the reconstruction of ecology.

(woman, visual arts)

Hope, values, and agency are interconnected: one's agency is tied to promoting one's values and this agency may be a part of work agency or transcend its boundaries, which also ensures the continuity of agency.

\section{Discussion and Conclusions}

This study on the first wave of the COVID-19 pandemic in Finland addressed the agency of cultural sector workers from the perspectives of time and space including their economic and employment situations. Agency in time and space was contextually defined: past efforts signified waste and loss when there were no opportunities to realize the results of one's work, but, depending on the form of agency, there could be also continuity in the present and independent of the form of agency, also in the future. Each temporal setting stood in relation to others, but future perspectives were the most open and had a strong element of hope despite the circumstances.

The economic and employment situation determined the opportunities for agency in two distinct categories. Normative work agency appeared as intensification of work and self-limitation of agency fueled by the comparatively better situation such as an employment contract or benefit. In practice this meant working harder with no extra rewards and refraining from activities detrimental to the survival of those in more precarious positions at that point in time. Normative employment agency was shaped by the negotiation of the boundary between art and non-art as a tradeoff: steady income, less chance of sticking to one's basic work be it cultural administration or personal artistic endeavors and in the latter case, poorer prospects for gaining recognition and awards as an artist. Intensification of work was also possible because of the new ways of organizing work, such as personal scheduling and other kinds of structuring of people's daily lives. The creation of structures was also a part of precarious work agency that appeared as skills of managing uncertainty 
and with low resources already obtained before the pandemic. Also, the ways to cope with the restricted circumstances differed: some felt incapable of doing artistic work, others used art as a way to work through the tough times. This was dependent on the resources available, such as the infrastructure required to enact work agency, on the income of a possible partner and on the chances of managing the boundaries of work and family when family responsibilities intensified.

Our study has relied on the conceptualization of agency, small agency in particular, in the context of precarious work in the cultural sector. To understand the nature of cultural workers' agentic possibility, we aimed to produce new knowledge about the dimensions of agency, especially in relation to time and employment arrangements as described. In line with Âkerblad [36], our analysis showed that employment type is not the only determining factor for feeling of security in working life. A precarious mode of working also affects the meanings of security: while precarious mode of working is not desirable, it does offer a chance or a necessity to halt, endure, wait, act differently, or think over. Åkerblad has pointed out that this means a need to think about uncertainty and certainty in the new ways and to create mental strategies and utilizing various discursive elements to live with the unpredictability and uncertainty. In the future, it would be fruitful to analyze factors that strengthen the understanding how continuity that is embedded in small agency provides opportunities for the new. The emergency hit artists and professionals in the cultural sector hard, but despite that, they felt guilty about having more income than some of their peers or about working insufficiently. The small world mindset penetrated their situation during the emergency. Does the mindset adjust to the worse situation in a way which even decreases the size of the small world? Does it narrow such perspectives that might provide new opportunities in the future? The small world mindset was not, however, a solid and uniform way of thinking and acting, for we recognized small deviations from it, assumptions of being worthy of something better.

However, adoption of the small world mindset is not socially and economically neutral, for risk-taking opportunities are related to resources provided by the economic, cultural, and social background. We assume that the unequal resources may shape the outcomes of artistic work, with the opportunity for free expression. Our data did not provide the opportunity to contribute on this perspective, but we recommend research on social class in studies of cultural work.

The agency during the pandemic followed the common pattern in the cultural sector, in other words, fragmented employment, small income, unpaid work, and insecurity and flexibility. However, the organization of life differentiated to some extent as regards the lockdown and terms for earning their living. The impacts on employment and activities were severe for the individual artists and enterprises, but for municipalities, with their obligation to provide library services and support cultural activities, less so. For the multiple job holders, the assignments were lost and the availability of even non-professional jobs was scarce.

The first wave of COVID-19 had a diverging effect on work agency: for some it meant intensification of work and for others loss of work and job opportunities and hence resorting to small agency. Although these two developments entailed different economic consequences, those with few chances to realize work agency were not merely enduring their circumstances. Small agency could be experienced in many ways, also as a condition that allowed for thinking and paved the way for creativity. Accepting that one could not act now, could also mean considering the future as something that would make change and realizing one's values possible. Conversely, those engaged in intensified work did not necessarily have time to think and take stock of the situation. Following Åkerblad's [36] idea of career hubs, the pandemic made it necessary to find new ways to act either in the short or the long term, depending on the emerging alternatives or the opportunities create new ways of acting. In the data there were examples of this, such as focusing on wellbeing instead of work agency or finding new methods or platforms to realize artistic endeavors. Changing temporal perspectives also made it possible to act or to construct the future 
in a way that allowed change to come and one to be a part of that change eventually by following one's values.

Work processes and control over them are central to understanding the applicability of new methods of work among the cultural sector workers. During the pandemic, some found new avenues of work and ways to express themselves artistically, while others struggled not only with the accessibility of skills but also with the very nature of work that may be incompatible with remote work or virtual settings. It would be beneficial for future research to engage in the premises of different types of cultural work and forms of art, on the platforms and in the contexts they are realized, in relation to the discussions on the future of work to understand the possibilities and limitations.

Author Contributions: Conceptualization, A.H., M.L. and K.O.-L.; methodology, A.H. and M.L.; formal analysis and investigation, A.H., M.L. and K.O.-L.; resources, A.H., M.L. and K.O.-L.; data curation, A.H., and M.L.; writing-original draft preparation, A.H., M.L., K.O.-L.; writing一review and editing, A.H., M.L., K.O.-L.; visualization, A.H., M.L., K.O.-L.; supervision, A.H., M.L. and K.O.-L.; project administration, M.L.; funding acquisition, A.H. All authors have read and agreed to the published version of the manuscript.

Funding: Tampere University funding for supporting research on pandemic and ESF (S22429).

Institutional Review Board Statement: The study was conducted according the ethical guidelines in the human sciences defined by the Ethics Committee of the Tampere Region. Ethical approval was not sought from a Institutional Review Board, since the data were collected on the platform of the Finnish Social Science Data Archive that follows ethical guidelines, all the research participants stayed anonymous to the researchers because of the collection process and they had control over what they wanted to share in their writings. Participation in the research was not possible without informed consent and the research did not include ethically problematic issues such as health information.

Informed Consent Statement: Informed consent was obtained from all subjects involved in the study.

Data Availability Statement: The data are stored and will be available in the Finnish Social Science Data Archive 1 January 2023 with the code FSD3470 Kulttuuriala koronapandemian aikaan-Kirjoitusaineisto 2020.

Conflicts of Interest: The authors declare no conflict of interest.

\section{References}

1. Ofori, F.N.K. Reflecting on the impact of COVID-19 pandemic on businesses, minority groups and their implications for socio-economic wellbeing in britain. Arch. Bus. Res. 2021, 9, 183-197. [CrossRef]

2. Milne, A.K.L. A critical COVID-19 economic policy tool: Retrospective insurance. SSRN 2020, 1-19. [CrossRef]

3. Ivey, G.W.; Lee, J.E.C.; Fikretoglu, D.; Guérin, E.; Frank, C.; Silins, S.; Pickering, D.I.; Thompson, M.M.; D'Agata, M.T. Chapter 12: COVID-19: Short- and long-term impacts on work and well-being. In A Research Agenda for Workplace Stress and Wellbeing; Kelloway, E.K., Cooper, C., Eds.; Edward Elgar Publishing: Cheltenham, UK; Northampton, MA, USA, 2021; pp. 211-234. [CrossRef]

4. Holst, H.; Fessler, A.; Niehoff, S. COVID-19, social class and work experience in Germany: Inequalities in work-related health and economic risks. Eur. Soc. 2021, 23, S495-S512. [CrossRef]

5. Jakonen, O.; Luonila, M.; Renko, V.; Kanerva, A. Katsaus koronan vaikutuksista taiteen ja kulttuurin alojen toimintaedellytyksiin ja kulttuuripolitiikkaan Suomessa. (An overview of the impacts of the COVID-19 pandemic on the fields of art and culture and cultural policy in Finland). Kultt. Tutkimuksen Vuosik. 2020, 5, 50-59. [CrossRef]

6. Betzler, D.; Loots, E.; Prokůpek, M.; Marques, L.; Grafenauer, P. COVID-19 and the arts and cultural sectors: Investigating countries' contextual factors and early policy measures. Int. J. Cult. Policy 2021, 27, 796-814. [CrossRef]

7. Gursoy, D.; Sarışık, M.; Nunkoo, R.; Boğan, E. COVID-19 and the Hospitality and Tourism Industry a Research Companion; Edward Elgar Publishing: Cheltenham, UK, 2021. [CrossRef]

8. Shin, H.; Nicolau, J.H.; Kang, J.; Sharma, A.; Lee, H. Travel decision determinants during and after COVID-19: The role of tourist trust, travel constraints, and attitudinal factors. Tour. Manag. 2022, 88, 104428. [CrossRef] [PubMed]

9. Eikhof, D.R. COVID-19, inclusion and workforce diversity in the cultural economy: What now, what next? Cult. Trends 2020, 29, 234-250. [CrossRef] 
10. Koronapandemian Vaikutuksia Kulttuurialalla 2020-2021 Raportti Kyselyn Vastauksista (Impacts of COVID-19 Pandemic in the Cultural Sector in 2020-2021 Report on Responses to a Survey). Available online: https://julkaisut.valtioneuvosto.fi/bitstream/ handle/10024/162973/VN_2021_26.pdf?sequence=1\&isAllowed=y (accessed on 10 October 2021).

11. OECD Policy Responses to Coronavirus (COCID-19). Culture shock: COVID-19 and the Cultural and Creative Sectors. 2020. Available online: https:/ / www.oecd.org/coronavirus / policy-responses/culture-shock-covid-19-and-the-cultural-and-creative-sectors08da9e0e/ (accessed on 14 October 2021).

12. European Commission. CORDIS EU Research Results. Finland, the World's Most Technologically Advanced Country-UN Report. 2021. Available online: https:/ / cordis.europa.eu/article/id/17266-finland-the-worlds-most-technologically-advanced-countryun-report (accessed on 14 October 2021).

13. Sutela, H.; Pärnänen, A. Koronakriisin vaikutus palkansaajien työoloihin (The Impacts of COVID-19 Pandemic on Workforce) 2021. Available online: https://www.stat.fi/tup/julkaisut/tiedostot/julkaisuluettelo/ywrp1_202100_2021_25870_net.pdf (accessed on 14 October 2021).

14. Haapakorpi, A. Jälkiteollinen yhteiskunta ja monista lähteistä ansainta-Tehtäväyhdistelmät ja tausta erilaisissa ammattiryhmissä (Multiple job holding in post-industrial society: Careers and context in different professions). In Useasta lähteestä ansaintaKäytännöt ja yhteiskunnallinen kehys (Multiple job holding_Practices and institutional framework); Järvensivu, A., Haapakorpi, A., Eds.; TUP-Tampere University Press.: Tampere, Finland, 2022; pp. 56-97.

15. Radermecker, A.S.V. Art and culture in the COVID19 era: For a consumer oriented approach. SN Bus. Econ. 2021, 1, 1-14. [CrossRef]

16. Dümcke, C. Five months under COVID-19 in the cultural sector: A German perspective. Cult. Trends 2021, 30, 19-27. [CrossRef]

17. Tajtáková, M.; Žák, Š.; Filo, P. The lipstick effect and outdoor cultural consumption in Slovakia in times of crisis. Ekon. Cas. 2019, 67, 607-628. [CrossRef]

18. Kuntaliitto (Association of Finnish Municipalities). Financial Support for Self-Entrepreneurs. 2021. Available online: https:// www.kuntaliitto.fi/elinvoima-ja-tyollisyys/kuntien-elinkeinopolitiikka/kuntien-myontama-yksinyrittajien-korona-avustus (accessed on 12 June 2021).

19. Eurostat. Culture Statistics—Cultural Employment. 2019. Available online: https://ec.europa.eu/eurostat/statistics-explained/ index.php?title=Culture_statistics_-_cultural_employment\#Cultural_employment_.E2.80.94_overall_developments (accessed on 15 December 2020).

20. Statistics Finland. Number of Persons Working in Cultural Occupations and Industries Increased in 2018 from the Year Before. 2019. Available online: http://www.stat.fi/til/klt/2018/01/klt_2018_01_2019-06-10_tie_001_fi.html (accessed on 15 November 2020).

21. Ross, A. The new geography of work power to the precarious? Theory Cult. Soc. 2008, 25, 31-49. [CrossRef]

22. Teissl, V.; Mayerhofer, E.; Reid, W. Austrian film festival forum: Cultural governance and accountability in Viennese film festivals. Int. J. Arts Manag. 2021, 24, 103-113.

23. Lindström, S. Artists and multiple job holding-Breadwinning work as mediating between bohemian and entrepreneurial identities and behaviour. Nord. J. Work. Life Stud. 2016, 6, 43-58. [CrossRef]

24. Bridges, L. Flexible as freedom? The dynamics of creative industry work and the case study of the editor in publishing. New Media Soc. 2018, 20, 303-1319. [CrossRef]

25. Hermes, J.; Koch, K.; Bakhuisen, N.; Borghuis, P. This is my life: The stories of independent workers in the creative industries in the Netherlands. Javnost Public 2017, 24, 87-101. [CrossRef]

26. McRobbie, A. Be Creative, 1st ed.; Polity: Cambridge, UK, 2016.

27. Rensujeff, K. Taiteilijan Asema 2010. Taitelijakunnan Rakenne, Työ Ja Tulonmuodostus. (The Position of Artists 2010. The Structure and Income of Artists); Taiteen Edistämiskeskus: Helsinki, Finland, 2015. Available online: https:/ /www.taike.fi/documents/10921/ 1094274/Taiteilijan_asema_2010_2.korjattupainos.pdf/f59aa7d3-f396-4340-81ac-2bac9d4ae841 (accessed on 15 December 2020).

28. Hesmondhalgh, D.; Baker, S. Sex, gender and work segregation in the cultural industries. Sociol. Rev. 2015, 63, 23-36. [CrossRef]

29. Throsby, D.; Zednik, A. Multiple job-holding and artistic careers: Some empirical evidence. Cult. Trends 2011, 20, 9-24. [CrossRef]

30. Throsby, D.; Petetskaya, K. Making Art Work: An Economic Study of Professional Artists in Australia. A Report Commissioned by the Australia Council. 2017. Available online: https://www.copyrightevidence.org/wiki/index.php/Throsby_and_Petetskya_ (2017) (accessed on 14 October 2021).

31. Emirbayer, M.; Mische, A. What is agency? Am. J. Sociol. 1998, 103, 962-1023. [CrossRef]

32. Heiskala, R. Toiminta, Tapa Ja Rakenne: Kohti Konstruktionistista Synteesiä Yhteiskuntateoriassa. (Agency, Custom and Structure: Towards Constructivist Synthesis in Social Theory), 1st ed.; Gaudeamus: Helsinki, Finland, 2000.

33. Leinikki, S. Pelon Ja Toivon Välissä: Pätkätyöläisen Urakerronta. (Between Hope and Fear: The Working Life Narrative of the Well-Educated Fixed-Term Employees). Ph.D. Thesis, Department of Sociology, Faculty of Social Sciences, University of Helsinki, Helsinki, Finland, 2009. Available online: http:/ / urn.fi/URN:ISBN:978-952-10-5515-7 (accessed on 1 December 2021).

34. Lähteenmaa, J. Nuoret Työttömät Ja Taistelu Toimijuudesta (Young Unemployed and the Struggle for Agency). Työpoliittinen Aikakauskirja 2010, 4, 51-63.

35. Lähteenmaa, J. Nuoret työttömät ja yliviritetty toimijuus. Nuorisotutkimus 2011, 29, 47-60.

36. Åkerblad, L. Epävarmuuden Tuolla Puolen. Muuttuvat Työmarkkinat Ja Prekaari Toimijuus. (Beyond Uncertainty. Changing Labor Markets and Precarious Agency). Ph.D. Thesis, University of Eastern Finland, Joensuu, Finland, 2014. 
37. Åkerblad, L. Hämmennystä ja reittivalinnan vaikeutta—Prekaari toimijuus. (Confusion and problems in career hubs—precarious agency). In Toimijuus, Ohjaus Ja Elämänkulku; Kauppila, P., Silvonen, J., Vanhalakka-Ruoho, M., Eds.; Reports and Studies in Education, Humanities, and Theology 11; The University of Eastern Finland: Joensuu, Finland, 2015; pp. 129-144. Available online: https:/ / erepo.uef.fi/bitstream/handle/123456789/15099/urn_isbn_978-952-61-1747-8.pdf?sequence=1 (accessed on 1 December 2021).

38. Honkasalo, M.-L. Katveessa: Pieni toimijuus näkökulmana toiminnan teoriaan. (Small world mindset as a perspective to agency theory). Tiede ja Edistys 2013, 38, 42-61. [CrossRef]

39. Rikala, S. Työssä uupuvat naiset ja masennus. (Exhausted women and depression). Acta Electronica Universitatis Tamperensis 2013, 1854. Available online: http:/ / urn.fi/URN:ISBN:978-951-44-9218-1 (accessed on 5 December 2021).

40. Morgan, G.; Nelligan, P. Labile labour-Gender, flexibility and creative work. Sociol. Rev. 2015, 63, 66-83. [CrossRef]

41. Silverman, D. Methods for Analysing Talk, Text and Interaction. In Interpreting Qualitative Data; SAGE: London, UK, 2006. 